\title{
Peace Treaties with Morocco, the Ottoman Empire, and the North African Regencies
}

At the end of the War of Spanish Succession the Bourbons consolidated their hold on the Spanish throne in exchange for several concessions, including the loss of their Italian domains. Philip v tried unsuccessfully to recover them, but from 1734 on his son, the future Charles III, wore the crown of King of Naples and Sicily. ${ }^{1}$ The Bourbons' North African policy produced better results: they strengthened their hold on the few territories Spain still held there and recovered some that had been lost. ${ }^{2}$ They managed to lift the siege of Ceuta initiated by Muley Ismail $(1694-1727)^{3}$ and to regain the presidio of Oran and its port at Mazalquivir, conquered by the Algerians in 1708.4 A Spanish fleet also helped to expel the Turks from Corfu in $1716 .^{5}$

At this point it had become clear that Spain's hegemony belonged to the past and that the nation had to accept the decline of its empire. Pressure from England and France forced the elites of the Bourbon state to adjust to the new times, and in the spirit of reform they refocused their attention on the Mediterranean. A new policy began to emerge vis-à-vis the Muslim enemy, who no longer seemed so fearsome as before. To assure the defense of Spain's southern flank, and navigation under the Spanish flag, the monarchy began to seek stable and permanent relations with Morocco, the Regencies, and the Ottoman Empire.

The Bourbons took some time to develop their negotiations with Muslim countries; we know little about the North African and Levantine policies of

1 Jover Zamora, España en la política internacional.

2 Abitbol, Histoire du Maroc, 250-53; Vilar and Lourido Díaz, Relaciones entre España y el Magreb; García-Arenal and Bunes, Los españoles y el Norte de África; Vilar Ramírez, Planos y mapas históricos de Argelia.

3 Posac Mon, “Traslado del emplazamiento"; Sanz Sampelayo, "Un informe anónimo"; Guastavino Gallent, "Los comienzos del sitio de Ceuta"; Galindo y de Vera, Historia, vicisitudes; Correa da Franca, Historia de la mui noble ... ciudad de Ceuta, esp. 675-828.

4 Bravo Caro, "Málaga en la logística de la Expedición a Orán"; Terki-Hassaine, "Liberación de Orán y Mazalquivir"; Alberola Romá, "El port d'Alacant”; Epalza, "La expedición de Alicante para la toma de Orán."

5 Fernández Duro, La Armada Española, 6:118-19. 
Philip v and Ferdinand vI, but their occasional dealings do not seem to have borne fruit. ${ }^{6}$ The most notable episode was a timid approach to the Regency of Algiers: its envoy visited Madrid in 1701 in an attempt to ensure Spain's neutrality in its conflict with Morocco. ${ }^{7}$ The thaw did not last long because Algiers, seizing an opportunity during the War of Spanish Succession, conquered Oran in 1708 and held it until Spain reoccupied it in $173^{2}$.

In the 173 os the monarch and his governing elites accepted fully Spain's status as subordinate to Great Britain and France, especially after its defeat in the War of the Quadruple Alliance (1717-1720). The nation's foreign policy turned toward alliances that might make English and French hegemony more bearable, beginning with a cautious diplomatic turn toward Morocco, the North African Regencies, and the Ottoman Empire. A sort of pre-agreement was reached with the sultan of Morocco in 1736, but progress was slow because influential sectors of Spanish society still opposed negotiations with "the enemy of the Faith." There was reluctance on the Moroccan side for similar reasons, and because the country smarted under Spain's occupation of towns on its coastline (Ceuta, Melilla, El Peñón de Vélez de la Gomera, and El Peñón de Alhucemas). ${ }^{8}$

By the second half of the eighteenth century, however, Spanish society had clearly come to favor peaceful relations with Muslim countries. ${ }^{9}$ When the Count of Floridablanca made his will, after the period of which we speak and referring to the peace with the Regency of Algiers, his words were just as applicable to the wish for a policy of peace with all four Maghrebi countries, then in the process of formation:

On this peace depends the safety of our coasts and our Mediterranean trade, increase of that trade and of agriculture, and even the supplying and protecting of our southern provinces. ${ }^{10}$

6 Windler, "La diplomacia y el 'Otro' musulmán" and "De l'idée de croisade”; Lepore, Un capitolo inedito.

$7 \quad$ See Chap. 4, section 4.1.

8 García-Arenal and Bunes, Los españoles y el Norte de África, 147; Lourido Díaz, Marruecos y el mundo exterior; Abitbol, Histoire du Maroc, chap. 8.

9 Beside the works that will be cited in the following pages see Epalza, "Intérêts espagnols et intérêts de la Turquie" and "Intereses árabes e intereses españoles."

10 "De esta paz depende la seguridad de nuestras costas y comercios del Mediterráneo, el aumento de éste y de la agricultura, y aún el abasto y socorro de nuestras provincias meridionales": Rumeu de Armas, El testamento político de Floridablanca, 120. 
Just at this time there were calls for abandoning the Spanish presidios on the North African coast, wholly or in part, since their occupation poisoned the country's relations with the Moroccans and Algerians. ${ }^{11}$

\subsection{Negotiations with Morocco: the Embassy of Al-Gazzal (1766) and the Treaty of Peace (1767)}

The king of Spain and the sultan of Morocco ascended their respective thrones almost simultaneously: Charles III in 1759 and Muhammad ben Abdallah in 1757. The latter, of the Alawite dynasty, soon showed an interest in establishing peaceful relationships with European powers. ${ }^{12}$ We have mentioned how influential elements in both Spain and Morocco were opposed to such relations, but mutual hostility benefited neither country and had to be brought to an end.13 By 1765 negotiations were well advanced, helped by two Spanish priests who were close to Muhammad Ben Abdallah's court. ${ }^{14}$ Finally in 1767 Jorge Juan went as ambassador to Marrakesh together with the Moroccan ambassador, Sidi Ahmed al-Gazzal, ${ }^{15}$ and the Treaty of Peace, Friendship, and Commerce was signed. ${ }^{16}$

The Moroccan representative had arrived in Spain a year earlier, in 1766 , to negotiate either a lasting truce or a permanent peace between the two countries, and his role in the final treaty was significant. Al-Gazzal, a native of Fez and a descendant of Andalusis, was one of the sultan's secretaries and would distinguish himself for his insight and effective writing, including the memoir of his diplomatic mission to Spain. ${ }^{17}$ Surviving documents attest to the esteem

11 Vilar Ramírez and Lourido Díaz, Relaciones entre España y el Magreb.

12 Abitbol, Histoire du Maroc, 269-78; Lourido Díaz, Marruecos y el mundo exterior and Marruecos en la segunda mitad del siglo XVIII.

13 Even in theological circles there began to be a current of greater respect and objectivity toward Islam, though always with apologetic and polemical features: Epalza, "Guerras y paces hispano-turcas."

14 Arribas Palau, "La estancia del padre Girón" and "El viaje de Fr. Bartolomé Girón"; Rodríguez Casado, "La política...Las misiones diplomáticas de Boltas y Girón”; Palacio Atard, "Primeras negociaciones entre España y Marruecos."

15 Sánchez Carrión, La embajada inacabada de Jorge Juan; Arribas Palau, "La acogida dispensada a Jorge Juan”; Rodríguez Casado, "La política...Las embajadas de El Gazel y Jorge Juan."

16 For an analysis of this first treaty see Martínez, "El Tratado de Paz de 1767"; Feria, "El tratado hispano-marroquí. I" and "El tratado hispano-marroquí. II"; Rodríguez Casado, $L a$ política marroquí de Carlos III.

17 Al-Ghazzal, The Fruits of the Struggle in Diplomacy and War (Arabic original in Bustani [ed.], Consecuencias del esfuerzo); Ben Hadda, A Moroccan Ambassador. 
in which Spanish authorities held him during his stay of several months. Carlos III called him "an ingenuous man, affable and well intentioned, recommended by his situation as well as by the respect that is due to his master." Members of his delegation included Sidi Amara Ben Musa, a relative of the sultan whose post was equivalent to leader of the cavalry; Sidi Eljas Mohamet Esiles, the ambassador's cousin; and "other lesser dignitaries," servants, and a few Spanish priests.

The delegation arrived in Ceuta on 22 May 1766 and boarded a xebec bound for Algeciras, where it docked on 29 May. Carlos III assigned them eight hundred reales a day and the use of a four-horse carriage. After the group left Algeciras "horsemen from one town would gallop along with them as far as the next one, where men of the principal families were proud of joining the race to the next one on the route." Authorities along the way to Madrid, and then back to Cádiz, made preparations to welcome them while multitudes of the curious gathered to view the procession at every stage. In a halt of two or three days in Medina Sidonia (because a servant had fallen sick) fêtes and bullfights were organized, and feasts and serenades entertained the Moroccans in Jerez from 9 to 14 June. When they reached Seville on 16 June the inhabitants "made a great show of happiness"; the ambassador was lodged in the Alcázar and visited the Giralda, later touring the mosque in Córdoba as well. Reaching Madrid on 11 July, the train entered through the Puerta de Atocha "in the sight of a large group of persons of all classes who had come out to meet them"; the delegation was housed in the Buen Retiro palace. ${ }^{18}$ In mid-October it left for Cartagena, meeting the same expectation as before in towns along the route and being received in similar fashion. In that port city al-Gazzal visited the slaves who worked on the shipyard and made some of the arrangements for their release that had already been agreed on. The next important stop was Granada, where an especially warm welcome was offered. Although the town council had received no instructions from the king it prepared the best reception it could, including theatrical performances:

For in spite of having no orders from the Court about demonstrations of welcome for him [the Moroccan ambassador], we have reliable accounts

18 Arribas Palau, "Algunos datos sobre el viaje”; Domínguez Ortiz, "Un embajador marroquí en Sevilla”; García Figueras, Embajada de El Gazzal; Commandant, "Une ambassade marocaine en Espagne"; Gorgous, "Ambassade marocaine en Espagne”; Velázquez y Sánchez, La embajada marroquí en 1766; Ramírez, Relación métrico-histórica. 
of how they have honored him in other capitals and towns, to the satisfaction of our lord the king. ${ }^{19}$

From Granada they traveled through the interior toward Osuna, Utrera, and Jerez, where the retinue rested for several days; after passing through La Isla de León they reached Cádiz on 7 January 1767. More feasting and dancing ensued until 19 February, when the Spanish and Moroccan embassies together boarded three xebecs in which they arrived at Tetouan on the following day. ${ }^{20}$

As for the embassy's business in Spain, al-Gazzal made his presentation to the king on 21 August, after which he entered into negotiations with the Secretary of State, the Marquis of Grimaldi. They reached agreement on the relevant points of the Treaty of Peace, which was to be signed and ratified by Morocco. (That was accomplished when the famous naval officer Jorge Juan, designated Minister Plenipotentiary, made a return visit to Morocco the following year.) Al-Gazzal's retinue began its journey home from Madrid on 5 October 1767.

Al-Gazzal, as we have mentioned above, had other orders from the sultan in addition to the treaty negotiations. He was charged with arranging contacts between the Spanish monarchy and the rulers of Algiers and Tripoli that would lead to similar treaties of peace, something considered essential if the friendly relations between Spain and Morocco were to last. He was also to make every effort to recover Arabic manuscripts from the library at El Escorial, and to ransom the greatest possible number of Muslim slaves.

Al-Gazzal received a few manuscripts from El Escorial:

Our stay in Madrid lasted one month after we took leave of the king, a period we spent awaiting the Islamic books that they had promised us, which were in the city. Since the king was not in the capital at the time of our departure he ordered the books removed from the place where they were kept and given to us, joining the books from Granada that we had brought with us. ${ }^{21}$

19 "[Q]ue sin embargo de no tener orden de la Corte para que se le hagan algunas demostraciones de obsequios, se tienen verídicas noticias de lo que en otras capitales y demás pueblos le han cortejado, y que ha sido del agrado del Rey nuestro señor": Valladar, "Un embajador de Marruecos en Granada."

20 Rodríguez Casado, La política marroquí de Carlos III, esp. chap. 3, "La embajada de Sidi Ahmet el Gazel," 67-93, 105-12; also his "Política marroquí de Carlos III."

21 "Nuestra estancia en Madrid, tras la despedida del rey, fue de cerca de un mes, tiempo que pasamos esperando los libros del Islam que nos habían prometido y que estaban en la ciudad madrileña. Como el rey no se hallaba en la capital en el momento de nuestra partida, ordenó que sacasen los libros del lugar en el que se encontraban y nos fueran entregados 
He presented both the manuscripts and the slaves he had liberated to the sultan:

We placed in the generous hands of our master the three hundred freed prisoners, men, women, and children, putting on the head of each of them a copy of those Islamic books that God had saved from the land of impiety through the blessing of our sultan, he who is victorious by the grace of God: works of hadith, Islamic jurisprudence, and other subjects. ${ }^{22}$

Al-Gazzal returned triumphant from his ransoming mission, since he was able to bring three hundred souls back to Morocco. When slaves had come out to meet his delegation in Cartagena he had promised to free them by any means possible:

These slaves are very poor and downtrodden, and what they earn after performing their service is not enough to feed their children, because prices are so high ... We spent a long time in their company while they wept and implored us, and we wept and lamented even more. ${ }^{23}$

Al-Gazzal was concerned not only for the Moroccans in Cartagena but also for the almost three hundred Algerians laboring on a highway in Segovia, and sick slaves being cared for at a hospital in Madrid. After difficult negotiations he was able to arrange freedom for the king's own slaves and a good proportion of those who were privately owned: altogether an additional five hundred, mostly Algerians but with some Turks, Tunisians, and Tripolitans. Almost all had been held in Cartagena, Barcelona, and Cádiz. ${ }^{24}$

para ser añadidos a las obras de Granada que venían con nosotros": Paradela Alonso, El otro laberinto, 69 .

22 "Pusimos en las generosas manos de nuestro señor a los trescientos prisioneros liberados, entre hombres, mujeres y niños, y colocamos sobre la cabeza de cada uno de ellos un ejemplar de aquellos libros del islam, que Dios había salvado del país de la impiedad por la bendición de nuestro sultán, el Victorioso por la gracia de Dios: obras de hadiz, de jurisprudencia islámica y de otras materias": Paradela Alonso, El otro laberinto, 71.

23 "Estos esclavos son muy pobres y miserables y lo que ganan, tras prestar sus servicios, les es insuficiente para alimentar a sus hijos debido a la carestía de los precios. ... Estuvimos largo tiempo en su compañía mientras ellos lloraban y suplicaban y nosotros llorábamos y nos lamentábamos aún más": Paradela Alonso, El otro laberinto, 65 .

24 Domínguez Ortiz, Sociedad y Estado, 338-39; Rodríguez Casado, La política, 69-88; Pérès, L'Espagne, 21-27; Arribas Palau, "Tres tetuaníes cautivos." 
The ambassador's next mission was even more significant: he went to Algiers in 1768 with orders from Sultan Muhammad ben Abdallah to negotiate for an exchange of captives and a peace treaty between Spain and Algiers. In October 1768 the Madrid press described how negotiations were proceeding, in spite of obstacles:

It is rumored that a truce or formal peace treaty will be arranged between this Regency and Spain, with the intervention of the Emperor of Morocco - from where two Ministers plenipotentiary have just arrived, one to negotiate the exchange of all the Spanish captives for the Algerian, Turkish, and Moorish ones held in Spain, and the other to propose at least a suspension of hostilities in the event that peace cannot be arranged. These negotiations give much displeasure to our corsairs, who make their fortunes by sailing the seas. But on the other hand we do not see ships arriving with valuable prizes, and even those seized in the last five weeks have been disputed or sued for, with the pretext of their passports. $^{25}$

To al-Gazzal's empathy for Muslim slaves who were not Moroccans we should add the sultan's declared concern, mentioned earlier, for the total elimination of legal slavery among Muslims and Christians. In September 1768 al-Gazzal signed an agreement with the administrator of the Royal Hospital of the Trinitarian Fathers, in the name of the king of Spain and the Dey of Algiers, ${ }^{26}$ to general satisfaction on both shores of the Mediterranean:

25 "Corre la voz de que se ajustará una tregua o paz formal entre esta Regencia, y la España, por interposición del Emperador de Marruecos, de donde acaban de llegar dos Ministros Plenipotenciarios, uno para negociar el cange de todos los Cautivos Españoles con los Argelinos, Turcos y Moros detenidos en España, y el otro para proponer á lo menos una suspensión de hostilidades, en caso de que no pueda ajustarse la paz. Estas negociaciones ocasionan bastante disgusto á nuestros Corsarios, acostumbrados á hacer su fortuna corriendo los mares. Por otra parte no se vén entrar embarcaciones con presas de valor, y aun las que se tomaron de cinco semanas á esta parte se disputan ó reclaman, con el pretexto de los Pasaportes": Gazeta de Madrid, 4 October 1768. See also Arribas Palau, "Una mediación de Marruecos."

26 Tratado del ajuste de canje y redención que el Excmo. Amet Elgacel, ministro del Emperador de Marruecos y el Reverendo Padre Predicador Mayor Fray Manuel Rozalen, administrador del Real Hospital de Padres Trinitarios calzados de la provincia de Castilla en España hiciera por orden y decreto de Su Majestad Católica con la Regencia de Argel, entre cautivos argelinos y españoles, con las condiciones siguientes, signed on 17 September 1768: for the full text see González Arpide, "La expedición de Argel." 
Word comes from Morocco that since that sovereign is satisfied with the zeal and skill with which Sidi Hamet Elgazel has carried out the various missions placed in his charge, and particularly in his embassy to Spain and his voyage to Algiers to arrange the exchange of Spaniards for Algerians, [the sultan] has again named him his Ambassador to the Ottoman Court. ${ }^{27}$

Between October 1768 and March 1769 1,301 Muslim slaves were freed and exchanged. ${ }^{28}$

This activity continued in the following years. In 1780115 Muslim captives were returned to the sultan of Morocco, ${ }^{29}$ and between 1766 and 1780 at least 2,405 corsairs ("Moorish prizes," moros de presa) were set free. The sultan pursued liberty not only for Moroccans but for all Muslims, especially Algerians since their numbers were greatest. At the same time, of course, Spanish slaves in Morocco were liberated. ${ }^{30}$

Al-Gazzal took an interest in many topics aside from his stated objectives, much as al-Gassani had done in an earlier era. He thought that he met descendants of Muslims wherever he went in Spain, especially in Andalusia:

There is no doubt that the two small cities of Villafranca and Palacios go back to al-Andalus. There we spoke with a man surnamed Blasco, a well-known notary who, because of his great fondness for us, must logically have been a Muslim. He began to give us secret signs and speak in a roundabout fashion because he could not declare openly what the matter was about. He brought a daughter of his who had Arabic features

27 "Escriben de Marruecos, que satisfecho aquel Soberano del zelo y acierto con que Sidi Hamet Elgazel ha desempeñado los varios encargos que ha puesto a su cuidado, y señaladamente en su Embaxada á España, y su viage á Argel para reglar el cange de los Españoles y Argelinos, le ha nombrado nuevamente su Embaxador á la Corte Otomana": Gazeta de Madrid, 3 October 1769 .

28 Blasco Leante et al., "La administración de la armada española"; González Arpide, "La expedición de Argel”; Bodin, "Une rédemption de captifs musulmans."

29 Arribas Palau, "Argelinos cautivos en España"; Bodin, "Une rédemption."

$30 \quad$ Mouline, "Un ambassadeur rédemptoriste"; Barrio Gozalo, Esclavos y cautivos, 146; Ben Driss, "L'impegno umanitario del sultano"; Lourido Díaz, Marruecos, 41-84, "La obra redentora del sultán," "La abolición de la esclavitud," and "Hacia la desaparición de la esclavitud"; Arribas Palau, "Un rescate de 6oo cautivos" and "El marroquí Muhammad b. 'Abd al-Hadi." Individual ransoms were also arranged: Lalla Fatma bint Muhammad b. Abd al-Rahman al-Sharif, a captive in Malta in the 179os, wrote twice to Muley Sliman asking to be ransomed together with her husband and a servant: Loukili, "D'une captivité musulmane à l'autre." 
and looked nothing like the Christians. In the afternoon a group of girls from Utrera came to greet us. They and the people of those two cities were identical in appearance and customs. Their blood was that of the Arabs and their characters opposite to those of the foreigners. Their inclination toward Muslims, their sympathy for them, and their sadness on taking leave were definite proofs that they descended from the Andalusis.

He met descendants of Muslims in eastern Spain as well. In Loja, "there were those who indicated their fondness for Islam in hidden fashion, and those who declared it openly." In Elche people behaved in a similar way: "they did all this in secret, because if anyone declared it openly and did not repent he would be condemned to death." ${ }^{11}$ Just as in al-Gassani's case, these demonstrations might have been mere tokens of courtesy and hospitality on the part of the people he met.

Also like his predecessor, al-Gazzal was filled with emotion on seeing the principal Islamic monuments or buildings in the Arab style. While lodged in the Alcázar in Seville he "observed the details of that beautiful edifice, which he continued to study with greater appreciation during his periods of leisure." He felt the same about the Giralda, and in Córdoba he was moved by his first view of the mosque:

And when we caught sight of the city from an elevation and saw the style of its houses, the loftiness of its minaret, and how the principal mosque, with its great height, stood out from all the other buildings, we felt such sorrow that our souls shriveled within us.

31 "No hay duda de que las dos pequeñas ciudades de Villafranca y Palacios son restos de al-Andalus. Nos entrevistamos allí con un hombre, apellidado Blasco, un ilustre notario que, por la gran inclinación que demostró hacia nosotros, era lógico pensar que fuese musulmán. Comenzó a hacer velados signos y a dar muchos rodeos en el discurso que nos dirigió porque no podía declarar públicamente lo que se encerraba en el asunto. Trajo a una hija suya que tenia rasgos árabes y que en nada se parecía a los rumíes. Por la tarde llegó un grupo de muchacahas de Utrera para saludarnos. Ellas, y la gente de las dos ciudades, eran de igual aspecto y costumbres. Su sangre era de la de los árabes y sus caracteres opuestos a los de los ayamíes. Su inclinación para con los musulmanes, su simpatía hacia ellos y su pesar en el momento de la despedida eran pruebas concluyentes de que eran descendientes de los andalusíes. ... [H]abía quien señalaba su inclinación hacia el Islam de forma oculta y quien lo pregonaba abiertamente. ... [H]acían todo esto en secreto, puesto que si alguno lo proclamaba en público y no se arrepentía estaba condenado a morir": Paradela Alonso, El otro laberinto, 86-87. 
On visiting it they "imagined that the walls and columns of the mosque were greeting us and smiling on us to relieve us of the great sadness we felt," and al-Gazzal kissed them. With great emotion he embraced two marble slabs inscribed with the words "In the name of God, the Merciful, the Compassionate," and bathed them with his tears. ${ }^{32}$

Al-Gazzal, like al-Gassani before him, directed many criticisms toward the Spanish society of his time. For him Spain was "the country of impiety" inhabited by "enemies of God," and he engaged in dialectic with Spanish priests as he was visiting the ancient Islamic mosques. ${ }^{33} \mathrm{He}$ too found women to be too free and Spanish men insufficiently jealous, ${ }^{34}$ and he disliked the bullfight. ${ }^{35}$ But he admired other things including many aspects of the administration, the economy (such as factories and shipyards), science, and social life. ${ }^{36}$

After al-Gazzal and Jorge Juan had completed their diplomatic task with the signing of the Treaty of 1767 , a new era began in which both countries tried to avoid possible conflicts: disagreements such as often arose in trade and diplomatic relations, and clashes between their respective armadas. In Morocco's case it was a corsair fleet, in Spain's a navy armed for war. Attempts were also made to limit any incidents around the Spanish presidios (Ceuta, El Peñón de Vélez de la Gomera, Alhucemas, and Melilla): when local Moroccans attacked, it was understood that the Spaniards could respond with rifle fire but not with cannon. In 1774, however, Sultan Muhammad Ben Abdallah insisted that the peace treaty was valid only at sea and not on land and therefore did not cover the presidios. When he assaulted them ${ }^{37}$ Charles III declared a war on Morocco that lasted into $1775 .{ }^{38}$

The new international relationship between the parties was never severed completely, however, and was fully restored with the agreement signed by Count Floridablanca, the first Secretary of State, and the Moroccan ambassador

32 "Y cuando divisamos la ciudad desde un altozano y vimos la edificación de sus casas, la elevación de su alminar y el modo en el que la mezquita aljama, por su gran altura, se distinguía de todos los demás edificios, sentimos en el alma tal pesar que el ánimo se nos encogió.... [L] llegamos a imaginar que los muros y las columnas de la mezquita nos saludaban y nos sonreían para aliviarnos del gran pesar que sentíamos": Paradela Alonso, El otro laberinto, $80-82$.

33 Paradela Alonso, El otro laberinto, 71, 74, 82.

34 Paradela Alonso, El otro laberinto, 74, 94-95.

35 Paradela Alonso, El otro laberinto, 96-97.

36 Paradela Alonso, El otro laberinto, 89-10o.

37 Lourido Díaz, "La plaza de Ceuta," "Estrategia militar y diplomática," and "El armamento y la asistencia técnica."

38 Rodríguez Casado, La política marroquí, 181-229; Lourido Díaz, Marruecos y el mundo exterior, 205-44. 
Ibn Utman in Aranjuez in $1780 .{ }^{39}$ Relations improved even more in 1785, when Floridablanca's nephew Francisco de Salinas went as envoy to Morocco and signed a new agreement, principally about commercial matters. ${ }^{40}$

One proof of these improved relations was that in the American War of Independence, in which England and Spain were on opposite sides, Morocco favored the latter country: it ignored English promises to send the Royal Navy to help conquer the Spanish presidios. The sultan went so far as to let the Spanish build a base for their anti-corsair fleet in Tangier that also served to harry English ships in the Strait of Gibraltar. Similar situations obtained in later AngloHispanic conflicts in 1797-1802 and 1804-1808.41

When the sultan died in 1790 and his son Muley al-Yazid ascended the throne, a new period of strain between the two countries led to warfare - provoked, in this case, by a Moroccan assault on Ceuta. The rupture was only with Muley al-Yazid himself, because his brothers Muley Hicham and Muley Sliman, who had strength in different areas of the Moroccan Empire and contended for his throne, continued in alliance with Spain. ${ }^{42}$

This conflict ended with the death of al-Yazid in 1792 - an event in which Spanish agents played some part. The new sovereign, Muley Sliman, reestablished cordial relations with Spain, and the improved climate culminated in a new peace treaty in $1799 .{ }^{43}$ At that point Morocco became a refuge for many Spaniards who were fleeing from political turmoil at home: the brutal Napoleonic invasion (1808-1814), the liberal Cádiz of the Constitution of 1812, a new absolute monarchy with the return of Ferdinand VII (1814-1820), the threeyear liberal interlude (1820-1823), and finally the restoration of the absolutist Old Régime from 1823 onward. ${ }^{44}$

The enormous political and economic difficulties that both countries suffered led to a cooling of their mutual relations, and for a period Spain had

39 Arribas Palau, "La reanudación de las relaciones comerciales" and "El texto árabe del convenio de Aranjuez"; Rodríguez Casado, "La embajada del Talbe Sidi Mohammed" and "Apuntes para una biografía."

40 Arribas Palau, "El texto árabe del arreglo comercial de 1785"; Morales, "La embajada de D. Francisco Salinas y Moñino."

41 Lourido Díaz, Marruecos y el mundo exterior, 447-63, and "Relaciones políticas anglo-marroquíes."

42 Carmona Portillo, Las relaciones hispano-marroquíes; García Figueras, "El auxilio a Mawlay Hisam."

43 Abitbol, Histoire du Maroc, 278-80; Arribas Palau, "El texto árabe del tratado de 1799."

44 Helped by the French military expedition called the "One Hundred Thousand Sons of Saint Louis": Posac Jiménez, "Tánger refugio de los liberales españoles”; Miege, "Les réfugiés politiques à Tanger." 
almost no activity in Morocco except for the struggles there between different groups of Spanish exiles. ${ }^{45}$ To make matters worse, embargoes were placed on importing foreign wheat into Spain in 1820 and, with greater efficiency, in $1830 .{ }^{46}$ The measures damaged Morocco severely, since its exports of cereals to Spain formed the basis for commercial exchanges between the two countries.

Hispano-Moroccan relations deteriorated drastically with France's seizure of Algiers in 1830 and its eventual conquest and colonization of the whole Regency. The action provoked panic in liberal factions in Spain, which saw themselves hemmed in by the French (who had sent the Hundred Thousand Sons of Saint Louis to crush the liberal government in 1823) now not just in the north but in the south as well. When France defeated the Moroccan army at Isly in 1844, the doors of that empire lay open to them. As a preventive Spain's army occupied the Chafarinas Islands in 1848. The notion arose that Spain's "natural" southern frontier should be at the Atlas Mountains, requiring it either to defend the sovereignty and integrity of the Sharifian empire or simply to conquer it to avoid being encircled by the French. Throughout the second half of the nineteenth century Spain's Morocco policy vacillated between aggression (the African War of 1859-1860 and the Melilla War of 1893) and defense of Morocco's territorial integrity against French and English pressures. The desire to conquer Morocco was tempered by the certainty that the extinction of its empire would work to the advantage of France and probably also of Great Britain.

\subsection{Negotiations with the Ottoman Empire and the Regencies}

We now turn back in time to speak of Spain's policies toward the other Muslim states in the Mediterranean. The impulse to negotiate was fueled by, among other things, a wish to reduce the number of enemies around the Mare Nostrum - something that would help to defend Spain's interests against France and England - and to expand the country's maritime commerce around its eastern and southern shores. Before the eighteenth century was out Spain signed peace treaties with the Ottoman Empire and the Maghrebi Regencies. ${ }^{47}$

45 García Franco, "Orígenes contemporáneos"; Posac Mon, "La difícil neutralidad de Marruecos"; Castell, La actividad de España en Marruecos.

46 Martín Corrales, "El patriotismo liberal español contra Marruecos" and Comercio de Cataluña, 77.

47 Benafri, "Las relaciones entre España"; Epalza, "Intereses árabes e intereses españoles"; Conrotte, España y los países musulmanes; Cantillo, Tratados, convenios y declaraciones depaz. 
The intial effort was directed toward a treaty with the Sublime Porte that would then lead to others with the Regencies. The Ottoman Empire also hoped to reduce the number of enemy nations and increase that of allied ones, especially after its battles with the Russian Empire, which between 1768 and 1774 had seized Crimea and destroyed the Ottoman navy.48 In 1775 the caliph and his grand vizier sent letters to Barcelona proposing a permanent peace between the Spanish and Ottoman empires. Spain's response began in 1777 when Count Floridablanca assumed the secretaryship of state, ${ }^{49}$ and the following year Juan Bouligny, a French merchant established in Alicante, sailed for Istanbul with his son Josep to negotiate a treaty that was finally signed in $1782 .{ }^{50}$

That treaty's existence encouraged the Bey of Tripoli to establish peaceful relations with Spain. The negotiations began in 1783 when the Bey sought the mediation of the Moroccan sultan, ${ }^{51}$ but in the end his help was not needed: talks proceeded swiftly and a treaty of peace and commerce was signed in $1784,{ }^{52}$ normalizing the relations between the two parties. ${ }^{53}$

Negotiations with the Regency of Algiers, on which Istanbul claimed to have little influence, proved more complicated, but talks had begun at an early date, if only on the subject of exchanging captives. Those exchanges increased just after the War of Spanish Succession. In 1721 the king ordered the chief supply officer of Catalonia to send a tartane, captained by Jean Roger of Marseille, to Algiers with twelve captive Algerians aboard; they were to be exchanged for officers and soldiers of the Regiment of Navarre who were held there. In the end Roger took on "twenty-nine Moorish men, Moorish women, and Turks, who will be used to increase the number of persons exchanged from the regiment of Navarre." ${ }^{54}$ The next year, 1722, another "group of Moors [was sent] to effect

48 Bunes, El Imperio Otomano; Aksan, Ottoman Wars, 1700-1870.

49 Hernández Sau, "Dádivas al estilo oriental", 122, "Merchants Between the Mediterranean Sea," "Gifts Across the Mediterranean Sea," “Juan de Bouligny's Embassy to Constantinople," and "De la infidelidad a la amistad."

50 Beside the references in the previous note see Sánchez Ortega, "Las relaciones hispanoturcas"; Epalza, "Intérêts espagnols et intérêts de la Turquie"; Garrigues, Un desliz diplomático; Conrotte, España y los países musulmanes, 67-98.

51 Arribas Palau, "La mediación de Marruecos."

$5^{2}$ The text is printed in Real Cédula de S.M. (1784) and reproduced in Conrotte, España y los países musulmanes, 99-115, 336-46. It is analyzed in Epalza, "El primer tratado de paz hispano-libio" (Arabic version in Revue d'Histoire Maghrébine).

53 Vilar, "El Consulado General de España en Trípoli," "Las relaciones de España con Libia," and "El patrimonio del Estado español en Trípoli."

54 The king ordered that the soldiers be placed in quarantine after their return to Barcelona: Ім нв, FS, Serie I, leg. 2, fols. 114, 123; 28 March 1721 and 16 April 1721. 
an exchange with individuals of the regiment of Navarre who are detained in that city." 55

A general exchange of slaves with Algiers that had been agreed to in 1766 did not come to fruition, perhaps because of Algerian suspicion of the peace negotiations between Spain and Morocco. But as we saw in the previous section, the Moroccan sultan sent al-Gazzal to Algiers in 1768 to begin negotiations on a possible treaty with Spain and an exchange of captives. The Gazeta de Madrid published the following notice:

The Dey had resolved to send the consul of the Venetian Republic to the court in Madrid to discuss an exchange of Moorish prisoners for Spanish slaves, and at the same time make peace proposals to the Catholic king. For this purpose that monarch would be sent a number of gifts: fifty Christian slaves with their children, fine horses with rich trappings, lions, tigers, and other wild beasts. The slaves had had their chains struck off and were on the point of embarking when they were suddenly returned to prison, without any notice of the true cause.

Ten months later a second report, with some clarification, appeared:

There is much displeasure here over the treaty of peace and friendship arranged between Spain and the Emperor of Morocco. A corsair from Salé requested permission last week to erect a new mast on his ship of the line, and was told to appeal to his good friends in Spain. The only permission he received was to repair his ship's hull, and having taken his munitions ashore and requested a piece of wood for the stem, not only was he answered in the same tone but when a certain exclamation escaped him the naval supply officer slapped and beat him, sending the corsair away without his munitions. ${ }^{56}$

55 That ship was the pink San José under the Minorcan captain José Ferrer; it flew the flag of England, which oversaw the transport. Ім нв, Real Acuerdo, 1, fols. $335^{-3} 36$.

56 "El Dey había resuelto embiar al Consul de la República de Venecia á la Corte de Madrid, para tratar de un cange de prisioneros Moros por los Esclavos Españoles, y hacer al mismo tiempo proposiciones de paz al Rey Católico. Con este motivo se debian embiar a aquel Monarca varios regalos, que habían de consistir en 50 Esclavos Christianos con sus hijos, hermosos caballos con ricos aderezos, leones, tigres y otras bestias feroces. Ya se habían quitado las cadenas á los Esclavos, y estaban á punto de embarcarse, quando repentinamente se les volvió á la prisión, sin que se haya podido penetrar la verdadera causa": Gazeta de Madrid, 7 January 1766. ... "Aquí ha causado mucho disgusto el tratado de paz y de amistad ajustado entre la España y el Emperador de Marruecos. A un Corsario Saletino que pidió licencia la semana última para poner nuevo mástil a su Navío, 
While the treaty with Algiers did not prosper, we have already seen that alGazzal was successful in the prisoner exchange and continued his talks. ${ }^{57}$ They resulted in an agreement with the Trinitarians of Algiers, approved by the Spanish monarch and the Dey, ${ }^{58}$ that allowed for an almost total exchange of the captives held by both sides. ${ }^{59}$

In parallel to these events, since little progress was being made toward a peace treaty, the monarchy intensified its military pressure to thwart corsair attacks by the Algerians. As a result, Spain improved its navy: beside ships of the line it favored a privateering fleet as an auxiliary to its armada, and those ships caused depredations among the Algerian corsairs. In 1775 a Spanish naval fleet bombarded Algiers, causing some members of the Dey's court to open negotiations with the Spaniards. France, fearing damage to its important trade with the Regency, tried to mediate between the two sides in $1776 .^{60}$ These events coincided with the Count of Aranda's ambassadorship in Paris, and he openly favored a change of policy toward Muslims:

We will negotiate with them as if they were English or French, for reasons of state and the proper motive of our interests; for these are interests that we agree on, and we permit the worship of any god since we are no longer in the ignorant centuries of the Crusades. ${ }^{61}$

se le respondió que recurriese á sus buenos amigos en España: únicamente obtuvo permiso de carenar su vagel; y habiendo desembarcado sus municiones de guerra y pedido un tablón que necesitaba, no solo se le respondió en el mismo tono, sino que habiéndosele escapado cierta expresión, el Intendente de Marina le dio de bofetadas y palos, despachando al Corsario sin municiones": Gazeta de Madrid, 25 November 1766.

There were rumors in Algiers of "a truce or formal peace between this Regency and Spain, with the intervention of the Emperor of Morocco." If it did not come about there was talk of a cease-fire that had disturbed the corsairs, since they were unable to take prizes: Gazeta de Madrid, 4 October 1768. See also Arribas Palau, "Una mediación de Marruecos." The Gazeta de Madrid expressed favor toward al-Gazzal's negotiations on 3 October 1769 .

58 Tratado del ajuste de canje y redención que el Excmo. Amet Elgacel, ministro del Emperador de Marruecos y el Reverendo Padre Predicador Mayor Fray Manuel Rozalen, administrador del Real Hospital de Padres Trinitarios calzados de la provincia de Castilla en España hiciera por orden y decreto de Su Majestad Católica con la Regencia de Argel, entre cautivos argelinos y españoles, con las condiciones siguientes, signed on 17 September 1768: full text in González Arpide, “La expedición de Argel.”

59 Blasco Leante et al., "La administración de la armada"; González Arpide, "La expedición de Argel"; Bodin, "Une rédemption de captifs."

6o Chaillou, "Un projet de négotiation."

61 "Negociaremos con ellos como si fueran ingleses o portugueses, por la razón de Estado, y los justos motivos de nuestros intereses, pues éstos son motivos consentidos, y 
When Count Floridablanca assumed the post of Secretary of State he gave a new impulse to the negotiations: in early 1777 he reported to the king on "the need to establish peace with the Africans, particularly the Algerians." At the same time he warned that "to make peace - whose usefulness I think we cannot doubt in the light of what I have explained - we must attend carefully to how the pact is drawn up." ${ }^{2}$ In that year an approach was made to Sidi Hassan, the Algerian vekaleti or Minister of the Navy, whom the Spaniards had held in captivity; after being freed he started a campaign in the Regency for an exchange of all slaves. ${ }^{63}$ Nothing was achieved, however, because neither country wanted to take the first step in public and errors were made in the negotiations. After that failure the Spanish fleet bombarded Algiers again in 1783 and 1784 , and while the assaults were unsuccessful, they probably weakened those Algerian authorities who were wholly opposed to peaceful relations. ${ }^{64}$

Talks continued, however, and after an initial agreement in 1785 failed to gain approval by the Spanish court, a definitive Treaty of Peace and Friendship was signed in $1786 .{ }^{65}$ Spain's continued possession of Oran and Mazalquivir, however, poisoned the relations between the two countries to the extent that, without a formal break in relations, Algiers renewed its attacks on both presidios in 1790 and 1791. Spain finally ceded the two enclaves in February 1792, in part because an earthquake had ruined their defenses. ${ }^{66}$ The royal decree that ordered them abandoned declared them "of no use whatever to either religion or the state. ... [I]ntelligent, experienced, and religious persons well known for their love of my subjects' welfare" recognized that "even before peace was made with the Regency of Algiers, the possession of Oran and Mazalquivir was more harmful than useful to the Monarchy." 67

Negotiations with the Bey of Tunis were opened in 1786, the year that the treaty of Algiers was signed. While they did not present as many problems as

permitimos la religión de cada Dios, pues ya no estamos en los ignorantes siglos de las Cruzadas": Rodríguez Casado, La política marroquí, v.

62 Terki-Hassaine, Relaciones políticas, 166-67.

63 Terki-Hassaine, Relaciones políticas, 166-67; Conrotte, España y los países, 117-83, 353-70.

64 Hassam, Les bombardements d'Alger.

65 Sabater Galindo, "El tratado de paz hispano-argelino"; Epalza, "Algunas consecuencias del tratado"; Terki-Hassaine, Relaciones políticas, "Discrepancias en la traducción," "Tratado de paz hispano argelina," and "Nouvelles considérations sur le Traité"; Windler, "La diplomacia y el 'Otro' "; Conrotte, España y los países.

66 Terki-Hassaine, "Liberación de Orán y Mazalquivir" and "Problemática cuestión de las posesiones."

67 Real Cédula de S.M. (1792). 
in the Algerian case, a Treaty of Peace between the two states was not signed until $1791 .^{68}$

These bilateral agreements established peaceful relations and freedom of shipping and trade between the parties. Additional clauses stipulated how Moroccans, Algerians, Tunisians, Tripolitans, and subjects of the Ottoman Empire were to be treated when they arrived in Spanish ports and cities; that is, they were to receive the same consideration as Spaniards in North African and Ottoman ones. As we have related above, slavery as applied to both Christians and Muslims disappeared with the signing of these treaties; afterward we can speak only of prisoners of war, such as the Moroccans who were seized in 1791 and freed in $1792 .{ }^{69}$

The treaties formed the basis for Spain's expansion of diplomacy in the Muslim Mediterranean: it appointed to each country a consul general and a varying number of vice consuls. ${ }^{70}$ In theory, under clauses of reciprocity, Muslim countries could name consuls and vice consuls in Spanish territories, but in fact they did not do so. Only the Ottoman Empire introduced an article that reserved them the right to name a representative to assist Ottoman subjects if necessary. Article 7 stated:

The Ottoman Sublime Porte, for the tranquillity and security of its subjects and merchants, shall be allowed to establish in His Catholic Majesty's dominions a representative, commonly called a Shegbender, to reside in the city of Alicante. And the aforesaid subjects of the Ottoman Sublime Porte shall be respected and privileged in the same manner as those of His Catholic Majesty in the Ottoman Empire. ${ }^{71}$

Spain initiated its consular network in Morocco in 1767 , the very year that the Treaty of Peace was signed: the interim consul general was Jorge Patissiati, of

68 Terki-Hassaine, "Mediación argelina”; Jerfel, "Les Soler de Minorque”; Conrotte, España y los países, $185^{-207,376-87 . ~}$

69 For the detained Moroccans see Arribas Palau, "Pescadores marroquíes apresados."

70 For an overview see Pradells Nadal, Diplomacia y comercio; Ozanam, Les diplomates espagnols. For the consuls see Jerfel, "Les Soler de Minorque”; Epalza, "Los Soler menorquines”; Loth, Arnoldo Soler.

71 "Será licito a la Sublime Puerta Otomana para la tranquilidad y seguridad de sus súbditos y mercantes el establecer en los dominios de su Majestad católica un procurador, vulgarmente llamado Shegbender, para residir en la ciudad de Alicante, y los mencionados súbditos de la sublime puerta otomana serán respetados y privilegiados de la misma manera que lo serán los de su Majestad católica en el imperio otomano": Conrotte, España y los países, 318 . 
Greek origin and already the vice consul for Holland. But the permanent post was given almost immediately to Tomás Bremond, a negotiator of French origin with ties to Alicante and Cartagena: he occupied it in Larache until 1774. His successor as consul general in Tangier was Juan Manuel González Salmón, a merchant from Santander (1783-1799), followed by his brother Antonio (17991810); the latter, originally a secretary, became first vice consul in Tangier and later consul general. Blas Mendizábal was the next to occupy that post (18101816). The vice consuls in Tangier and Tetouan were respectively Jorge Patissiati (1767-1774) and Francisco Pacheco (1767-1774). Others were, in Tangier, Luis Goublot (1802-1808); in Larache, José de la Cruz (1802) and Juan Campuzano (1802-1808); in Salé, Juan Campuzano (1802); in Mogador, Gabriel Gavaró, a Majorcan who had spent many years as a captive in the emperor's court (17671774 and $1785^{-1790)}$. The latter alternated with Pedro Suchitá (1770-1782) and Antonio Rodríguez Sánchez (1782-1802)..$^{72}$

The successive Spanish consuls in Algiers were Miguel Larrea Salcedo (17941802) and Pedro Ortiz de Zugasti (1803-1809). In Oran, the vice consuls Juan Garrigó (1789-1791) and José Higuero (1796-1808). In Bône, Bartolomé Escudero (1792-1799), Juan Vigo (180o-1807), and Agustín Xiclona (1807-1814). In Tunis, Manuel Ventura Buzarán (1792-1799), Ignacio Buzarán (1799), Luis Castillo (1801-1803), Juan Francisco Fabre (1801-1803), and Arnoldo Soler (1804-1808). In Tripoli, Jaime Soler (1800-1801) and José Moraes (1801-1809). ${ }^{73}$ In the Levant the consuls were N. Francischi in Smyrna (1786-1799), Francisco Creus Soler in Smyrna and Alexandria (1789-1815), Carlos Smith in Aleppo (1785-?), and Miria Micri in Athens (1789-1799). ${ }^{74}$

Before concluding this section we should note that Spanish negotiations for biliteral treaties with authorities in Muslim countries left a great deal to be desired. It has been claimed with some truth that Spain's relations with Muslim lands in the eighteenth century were placed on a secular basis only at a late date, ${ }^{75}$ so that peace was not effectively established until the end of the 1700 . But we believe that this view needs modification.

It has also been affirmed, again accurately, that Spain lacked professionalism in its diplomatic negotiations with these countries, and that responsibility

72 Pradells Nadal, Diplomaciay comercio, 632-51; Ozanam, Les diplomates espagnols; Arribas Palau, “Juan Manuel González Salmón” and "El ceutí Francisco Pacheco."

73 Pradells Nadal, Diplomacia y comercio, 632-51; Ozanam, Les diplomates espagnols; GafsiSlama and Epalza, "Texto sobre la llegada del cónsul general."

74 Pradells Nadal, Diplomacia y comercio, 632-51; Ozanam, Les diplomates espagnols; Hernández Sau, "Juan de Bouligny's Embassy" and "De la infidelidad a la amistad." Windler, "La diplomacia y el 'Otro' " and "De l'idée de croisade à l'acceptation." 
often fell on individuals who were unprepared and even reckless: G. de Souza, the Count of Expilly, A. Basellini, J. de Mazarredo, F. Seguí, and J. Bouligny are among those cited in this regard. There is also truth to the claim that Spain's diplomatic network in the Maghreb and the Ottoman Empire was weakened by its reliance on certain families that placed their own interests above those of the state: one of those was the Soler clan, scattered as consuls around Tunis, Tripoli, and the Ottoman Empire. ${ }^{76}$ Without a doubt pressure from these oligarchic groups sometimes stood in the way of sensible action, and some talks were assigned to persons who were so ill prepared or unworthy of confidence that their negotiations stumbled. Future research might take up the question of whether there was any consistency in the manner of designating ambassadors, envoys, consuls, and vice consuls given the resources available at the time.

There was some pragmatism, however, in the naming of consuls and vice consuls in Muslim countries. The early ones were often merchants who had some degree of knowledge and prestige in their countries of destination: one of these was J.M. González Salmón, perhaps the most distinguished diplomat sent to any Muslim country at this period. Two others, both of French origin, were T. Bremond (sent to Morocco) and J. Bouligny (assigned to the Ottoman Empire). Members of the Soler family of Minorca drew on their experiences as subjects of England on their assignments to Tunis, Tripoli, Egypt, and the Ottoman Empire. Even some former slaves who had forged close relationships with their former owners came to play important roles at the North African courts: two sent to Morocco were P. Umbert, who had been secretary to the sultan, and G. Gavaró. We have seen how Spanish priests and friars played active roles in Morocco, both during the negotiations for peace treaties and in their maintenance afterward. The correspondence of Fathers B. Girón, J. Boltas, and others who led the Catholic establishments in Marrakesh and Meknes - the principal courts of the sultans of Morocco - reveals that they generally acted for reasons of state, not of religion. Any religious benefits were meant simply to help Christians living in those two cities, whether enslaved or free.

Recruitment of such diplomats and unofficial agents does not seem to have been so careless after all. It took place in the context of rivalry with Great Britain and France, the two powers that controlled most commerce with the Maghreb and the Ottoman Levant and did everything possible to impede Hispano-Muslim negotiations. ${ }^{77}$ Even so, some of Spain's consuls

\footnotetext{
76 Windler, "De l'idée de croisade."

77 Terki-Hassaine, Relaciones políticas, 171-76; Pradell Nadal, Diplomacia y comercio; Epalza, "Intérêts espagnols et intérêts de la Turquie" and "Intereses árabes e intereses españoles."
} 
were of French origin and others had clear sympathies with the English. While no thorough study has yet been made, there seems no doubt about the success of the brothers J.M. and A. González Salmón as consuls in Tangier, and the same can be said of the Solers in Tunis, Tripoli, and the Ottoman Empire. Though we have cited publications on these figures, they still await definitive studies.

We should also recall that the Spanish court turned to mediation by the Moroccans, Algerians, and Tunisians during its attempts to reach accords with North African countries, ${ }^{78}$ while acting as an intermediary in turn when Morocco began to seek peace negotiations with European nations. ${ }^{79}$

\subsection{A Surge in Spanish-Muslim Trade}

The gradual process of signing treaties between Spain and North African and Ottoman rulers brought about an increase in trade between the two sides. In these exchanges Spain's imports of wheat and barley dominated, as they had in the previous centuries. There has been research on this trade in relation to both the North African countries and the Ottoman Levant. ${ }^{80}$

Morocco provides the clearest case: the volume of trade between that country and Spain increased steadily between 1767 and 1814 . Two principal products were involved. The first was grain for human and animal consumption (wheat and barley, respectively) that left Morocco's Atlantic ports, ${ }^{81}$ especially Dar al-Beida (Casablanca), ${ }^{82}$ Mogador, ${ }^{83}$ and Safi. Grain from Morocco fed the principal cities of the Andalusian coast like Cádiz and Málaga, as well as Melilla, Ceuta, Alicante, Barcelona, Majorca, and the Canaries. Its chief buyer was the Spanish state, to supply its infantry and navy as well as its garrisons in the North African presidios, and other important purchasers were charitable foundations and institutions. At times of poor harvests in Spain and the resulting

78 Terki-Hassaine, "Mediación argelina"; Arribas Palau, "La mediación de Marruecos."

79 Arribas Palau, "La mediación de Marruecos," "La accesión de Fernando IV," and "Una mediación de Marruecos entre España y Argel.”

8o Martín Corrales, "Comercio en la frontera," "La saca de plata americana," "The Silk Trade," "El comercio de la seda," "Exportación del vino catalán," "El comerç de Catalunya," and "Il comercio della Catalogna."

81 Lourido Díaz, "El comercio del trigo" and "Los intercambios mercantiles"; Arribas Palau, "Datos sobre el comercio"; Ruiz Orsatti, Relaciones hispano-marroquies.

82 Arribas Palau, "Reclamaciones del marqués de Viale," "Cartas del Sultán Mawlay al-Yazid," and "Establecimiento de una casa comercial."

83 Martín Corrales, "Relaciones de España con Marruecos." 
high prices, the cheapness and ready availability of Moroccan wheat made it a necessity. At the same time, Spain's ability to import massive shipments from Morocco kept the price of European grain low. Though the topic needs further study, we assume that national and local authorities could manage lean years as long as they had easy, low-cost access to Moroccan wheat. Spain, throughout our period, formed the natural market for any surpluses of wheat, barley, and livestock from Morocco.

Other important imports beside grain were livestock (especially oxen), dried peas and beans, oranges, and chickens; these were loaded at the ports of Tangier, Larache, and Tetouan. Wax, hides, and textiles came continually from all those ports as well. ${ }^{84}$ There was so much light traffic between ports in northern Morocco and those on the coasts of Cádiz and Málaga that it hardly appears in the records, and its volume is hard to assess. When the ambassador from the Sublime Porte, Vaçif Efendi, was in Spain in 1787-1788 he observed that Spain's dependence on imports of food from Morocco was

the reason that the Spanish court pays so much deference to the government in Fez. The latter obtains, in exchange for the cereals it sells at high prices, ingots of gold and silver that it later sends to Spain to be minted into coins. 85

Although he was mistaken about the price of Moroccan wheat, which was actually much cheaper than wheat from elsewhere, the same observation could be applied to Spanish trade relations with the other North African countries and the Ottoman Empire.

84 Arribas Palau, "Una partida de cera”; Posac Mon, "Las relaciones comerciales entre Tánger y Tarifa"; García Figueras, "Un intento no culminado."

85 Paradela Alonso, El otro laberinto, 102-O3. In Meynard's account, "Tous les trois ans l'Espagne envoie dans les mines du Nouveau Monde cinq ou six millions de travailleurs; mais le plus grand nombre succombe sous l'influence de ce climat meurtrier. Aussi la population diminue de jour en jour, les bras manquent à l'agriculture, et c'est à l'Afrique que ce pays demande une grande partie de sa subsistence. C'est pour cette même raison que la cour d'Espagne use de tant de ménagements envers le souverain de Fez. Ce dernier, en échange des grains qu'il vend à des prix élevés, reçoit de l'or et de l'argent en lingots; il les fait convertir en monnaies par le gouvernement espagnol, auquel il envoie à cet effet la matrice portant l'exergue de l'avers et du revers; puis il fait venir les espèces dans son pays, évitant ainsi les frais de fabrication. Le fait que je rapporte est bien connu à Madrid": Meynard, "Ambassade le l'historien Vaçif Efendi," $5^{20-21}$. Hundreds of thousands of the sultan's gold bars were deposited in Cádiz, then minted into Moroccan coins in Madrid: Arribas Palau, "Barras de oro del sultán." Ruiz-Orsatti, Relaciones hispano-marroquíes. 
Spain's most important export to Morocco was silver piasters, ${ }^{86}$ though there were also luxury goods destined for the elites. ${ }^{87}$ The Spanish ports most active in trade with Morocco were Cádiz, ${ }^{88}$ Barcelona,${ }^{89}$ Ceuta, ${ }^{90}$ and those of the Canary Islands, ${ }^{91}$ though many others participated as well.

Trade with the Regency of Algiers followed similar lines, and again wheat and barley were the principal products. A great deal of grain was exported from Oran as well, together with a variety of other goods. ${ }^{92}$ Spanish coral fishermen also worked along the Algerian coast. ${ }^{93}$ Spain's largest export to Algiers was silver, just as it was to Morocco. The port of Algiers played an important role in this trade because the Spanish consul resided there, and his signature certified that shipments were legal and that there was no plague in the Regency at the time. Oran (which Algiers repossessed in 1792), Bône, and other ports were also active export centers. ${ }^{94}$

Trade with the Regency of Tunis was much like that with Morocco and Algiers, with a somewhat greater variety of exported goods, principally cereals and dried beans; these were paid for with Spain's renowned silver pieces from America. The busiest Tunisian ports were Tunis, Bizerte, Sousse, and Sfax. ${ }^{95}$ The Regency of Tripoli, on the other hand, conducted little trade with Spain. ${ }^{96}$

Commercial activity with the Ottoman Empire was significant, and centered almost entirely on continual importation of wheat (somewhat less of barley). While there was always wheat grown in lands ruled by the Ottomans,

86 Cano Borrego, "La circulación de la moneda española"; Martín Corrales, "La saca de plata americana."

87 Koehler, "Ce que l'économie privée importait."

88 Farouk, "Aperçu du trafic du port de Mogador."

89 Martín Corrales, "El comercio de Cataluña con Marruecos"; Arribas Palau, "Una reclamación marroquí."

90 Arribas Palau, "Gestiones de la Junta de Abastos."

91 Santana Pérez and Santana Pérez, La puerta afortunada; Arribas Palau, "El canario Pascual Rodríguez" and "Notas sobre el abastecimiento de granos"; Martín Corrales, "Atraso tecnológico de la pesca"; Bethencourt Massieu, "La pesca en la costa de África."

92 Terki-Hassaine, Relaciones políticas y comerciales; Martín Corrales, "Intercambios comerciales entre Málaga y Argel”; Vilar Ramírez, "Relaciones diplomáticas y comerciales," "Los judíos de Argel," and "Relaciones comerciales hispano-argelinas."

93 Martín Corrales, "La pesca española en el Magreb" and "Los coraleros catalanes en el litoral argelino."

94 Terki-Hassaine, Relaciones políticas y comerciales; Martín Corrales, "Intercambios comerciales entre Málaga y Argel.”

95 Martín Corrales, "Comercio de Túnez con Cataluña" and "Relaciones comerciales entre la Regencia de Túnez y Cataluña."

96 Martín Corrales, "El comerç de Catalunya" and "Il comercio della Catalogna." 
most imported wheat came ultimately from Russian Crimea. ${ }^{97}$ Other products from the Levant such as cotton and drugs usually did not arrive by a direct route but passed first through Marseille and Livorno. ${ }^{98}$ Spanish exports to Ottoman ports consisted fundamentally of consignments of American silver. ${ }^{99}$

Attempts were made to encourage exports of manufactured items from Spain and its American colonies, including textiles (silks and woolen caps) and wines, to North Africa and the Levant, but they did not achieve the hoped-for success. ${ }^{100}$

Most maritime commerce between Muslim and European countries had been carried out in European ships; but we have seen how the Spanish flag flew in the Ottoman Levant only in the first half of the sixteenth century, the 158 os and 159os, and the first few years of the 16oos. Throughout the Early Modern age Spain received direct shipping from Maghrebi ports, but with certain limitations. Most trade between European and Muslim lands occurred in vessels that flew the French, English, or other flags.

All this changed once there were peaceful relations between Spaniards and Muslims and trade increased as a result. Little by little Spanish ships took over the lion's share of maritime commerce between the two shores of the Mediterranean, eventually acquiring full control of direct shipping between North African ports and the Iberian Peninsula and plying the waters of the eastern Mediterranean once more.

More surprising was the appearance in Spanish ports, even in its American colonies, of ships flying the flags of Morocco, Algiers, Tunis, and the Ottoman Empire - in the latter case they were polacres with Greek captains. Because of Spain's wars with France (1793-1795 and 1808-1814) and Great Britain (17791783, 1797-1802, and 1804-1808) its trade declined in this period, especially while the English were blockading its coasts. But those same conflicts increased its trade with neutral parties: vessels of non-belligerent nations brought all sorts of necessary goods from North Africa and the Levant, especially wheat and barley, into Spanish ports. As neutral countries Morocco, Algeria, and Tunis provided many ships that allowed commerce between Spain and North Africa

97 Martín Corrales, "Capitaines et navires gréco-ottomans," "Greek-Ottoman Captains," "La flota greco-otomana en Cádiz," "El comercio de Cataluña con el Levante Otomano," and "Cereales y capitanes greco-otomanos."

98 Martínez Shaw, "Entre Oriente y Occidente."

99 Franch Benavent, "El fomento con el Levante mediterráneo"; Martín Corrales, "Una oportunitat perduda per Barcelona."

100 Martín Corrales, "The Silk Trade," "El comercio de la seda," and "Exportación del vino catalán”; Palacio Atard, "Intento de penetración en el mercado musulmán." 
as well as coastal trade among ports in Spain itself. ${ }^{101}$ They even sailed as far as the American colonies, particularly ships flying the Ottoman flag that traded in Río de la Plata. ${ }^{102}$

At this turbulent period a short-lived North African merchant marine emerged, though sometimes involving Spanish vessels sailing with passports from Morocco or Algiers. This traffic meant that more North African and Levantine captains, sailors, and merchants disembarked in Spanish ports - especially from Barcelona to Málaga on the Mediterranean and Cádiz on the Atlantic, but they also ventured to Galicia in the northwest and to the northern coast along the Bay of Biscay.

\subsection{The Treaty of Peace, the Gift Economy, Local Custom, and the Market}

When Christian and Muslim countries established peaceful relations through capitulations and treaties, each side understood the agreements in its own way. The Muslim powers designated all Christian lands as dar al-harb, "the house of war," as opposed to dar al-Islam: they believed in a divine right that denied legitimacy to any juridical order except their own. In Islamic lands the law (sharia, with figh as its form of jurisprudence) gave Muslims a monopoly of power over protected minority communities, which enjoyed a form of legitimacy and internal autonomy but always in a subordinate status. Christians could live there as long as they recognized Islamic rule and obtained safe-conducts for travel, though temporary truces or peace agreements were possible. The Ottoman Porte conceived of its capitulations to France and England in the sixteenth century, and to the Low Countries early in the seventeenth, as unilateral promises of security, even though that contradicted the underlying principle of reciprocity that for the Europeans was a droit des gens or Law of Nations. The Ottomans saw themselves as making temporary and voluntary concessions based on the aman or safe-conduct, which would have to be renewed whenever a new sovereign ascended the throne. They considered European consuls and other representatives residing in the Empire, who were actually laymen, as heads of religious communities who were granted the privilege of conducting their internal affairs. The European nations that imposed those

\footnotetext{
101 Martín Corrales, "La flotte marocaine."

102 Martín Corrales, "Capitaines et navires gréco-ottomans" and "Greek-Ottoman Captains"; Marichal, "El comercio neutral”; Malamud Rikles, "El comercio de Buenos Aires."
} 
capitulations were forced to accept the status of "protected minorities" at least until the start of the eighteenth century, as long as the Ottoman Empire could still present itself as a great power.

Alongside this subordinate position, European representatives to the Levant enjoyed significant economic and mercantile advantages. One was almost complete control of the Ottomans' and Regencies' external and maritime trade, which was consigned essentially to French, English, and Dutch ships. ${ }^{103}$ Politically, they were allies of the Sublime Porte in its confrontations with the Spanish Hapsburgs; militarily and economically, their merchant ships were exempt from attack by Muslim corsairs.

Christians came out of the casuist tradition of the rights of persons, which regulated their interactions with non-Europeans and non-Christians, among them Muslims. The principle of natural justice presupposed certain universal norms that should be shared by all; these should be subject to arbitration by tribunals agreed on by both sides. These notions formed the basis for a system of international law based on reciprocity; yet during the Enlightenment it excluded dealings with "uncivilized" persons, meaning in effect all nonEuropeans (with the exception of North Americans). ${ }^{104}$

We should therefore understand the capitulations as the development of specific political and juridical practices that included Christian princes and sultans within a common diplomatic space. Their periodic renovation allowed envoys to propose or demand concessions on the sultan's part when legal disagreements needed to be resolved. Juridical practice was thus gradually adapted to the specific needs of European merchants. In short, each side brought its particular concept of law to bear, to the extent that its power allowed. It is no surprise that, as the Ottoman Empire declined and French and English hegemony increased, the capitulations became instruments of the Sublime Porte's dependency. ${ }^{105}$ As the power of the Muslim states sank and that of the Europeans rose, contact between their respective legal systems gave authority to their agents to interact. European consuls, merchants, and sailors in lands of Islam, in particular, could reach agreements based on their own codes and values in given situations, whenever mutual understanding and interest made it possible.

103 Christians could live in Islamic lands so long as they acknowledged the dominion of Islam, and therefore European consuls were seen more as dhimmis, members of protected Christian communities, than as diplomatic representatives of a nation-state. Our Section 5.4. is essentially based on Windler, La diplomatie.

104 Pagden, European Encounters and Señores de todo el mundo.

105 Windler, La diplomatie, 220-22. 
The Muslim states wavered between initial hostility and a pragmatic search for legal guarantees. Meanwhile, Europeans established in Istanbul and Levantine ports tried continually to arrive at common norms that would ensure peaceful interchanges. Gradually, therefore, thanks to individual and collective initiatives, European law was systematically inserted into a plural diplomatic order, obeying the practical need to organize coexistence in the Mediterranean. C. Windler has advised that, given the profound divergence between the two legal systems, it is best to analyze "the juridical spaces that are created through continuous practice."106

In effect, European consuls in their daily practice "established structures of domination, defined spaces for action, and conditioned processes of exclusion." They contributed to molding Orientalist discourses that they then used to explain the difficulty or inefficacy of their activities. They themselves called those discourses into question, since they were being imposed on the complex reality in which they moved, their identities needing constant redefinition:

[Law] was created and recreated through diplomatic exchanges. The imaginary of a "barbaric Barbary" hid a multiplicity of contacts - occasions for conflicts but also for the resolution of those conflicts, and for creating personal ties that blurred the dichotomy "Europeans-Maghrebis."107

Until now studies of relations between Europeans and Muslims in this regard have dealt only with cities and ports in Islamic lands, neglecting interrelations among tradesmen and Muslim envoys on European soil.

In the Maghreb from the seventeenth century onward, treaties of peace and commerce led gradually to a system of contractual and customary law that combined norms of both Muslim and European origin. Agreements were always based on a unilateral obligation by the parties according to their respective laws:

Maghrebis and Europeans, in their contacts, respected a foundation of common rules hallowed by treaties and usage, which Frenchmen of the time - consuls, dragomans (interpreters), and bureaucrats, first of the

\footnotetext{
106 Here I follow Windler, who in turn draws on S. Ceruti, F. Barth, and others: Windler, $L a$ diplomatie, 214-15.

107 "[Le droit] était crée et recrée à travers les échanges diplomatiques. L'imaginaire de la 'Barbarie barbare' dissimulait la multiplicité des contacts - occasions de conflits, mais aussi de la résolution de ces conflits et de la création de liens personnels qui brouillaient la dichotomie Européens-Maghrébins": Windler, La diplomatie, 244.
} 
Navy and then of Foreign Affairs - interpreted as their particular legal system. ${ }^{108}$

The Regencies of Algiers, Tunis, and Tripoli made true treaties with France, "sealed and ratified by both parties as subjects of one Muslim-Christian law." Their duration was not tied to a single prince's reign; they were signed as if in perpetuity, a violation in principle of the advice of Muslim jurists and men of religion, though they did accord with Islamic law in their promise of mutual security. In case of conflict the Regencies would accept only the Turkish version, not recognizing any legal system except their own. ${ }^{109}$

In the end, negotiation and communication between Maghrebis and Europeans had to take account of not only the texts of signed treaties but also the principles, usages, and local customs of each side: "Treaties and usage delimited a shared juridical field, a space of relationships and transactions." ${ }^{\prime 10}$ As the case of France and Tunis demonstrates, it was impossible to impose every article in a given treaty unilaterally. ${ }^{111}$

On the Spanish side it was always possible to sign treaties with Muslim princes: in the Introduction we mentioned those ratified with the rulers of North Africa, from Morocco to Egypt, between 1492 and 1574. When the Hapsburgs and Osmanlis first began arranging truces in the early 1580s HispanoOttoman relations were not peaceful but neither were they bellicose, except for encounters between Spanish ships and corsairs from the Regencies. Still, no other treaties were signed beside that of 1767 with Morocco, the one country that the Ottomans never occupied. I will therefore focus here on relations with the rest of the Maghreb, where Ottoman power was more nominal than actual. The treaties signed between 1767 and 1791 ended a period of mutual hostility between Spaniards and Maghrebis that interfered with communications and trade, although commercial activity never ceased. In this new era it became urgently necessary to resolve issues that had led to conflict in the past: in particular, how to deal with cultural diversity and avoid dangerous misunderstandings. The situation required a pragmatic search for legal security

108 "Maghébins et Européens respectaient, dans leurs contacts, un fonds de règles communes, consacrées par les traités et l'usage, que les practiciens français de l'époque -consuls, drogmans (interprètes), commis de bureaux de la Marine, puis des Affaires étrangères- interprétaient comme un droit particulier": Windler, La diplomatie, 16.

109 Windler, La diplomatie, 224-25.

110 Windler, La diplomatie, 16.

111 Windler, La diplomatie, chap. 2. 
through negotiations, to ensure mutual respect for whatever specific norms were agreed upon.

At the time of the 1767 treaty with Morocco, each side's concept of its relationship to the other had changed significantly, as we suggested at the beginning of this section. Since the previous century Morocco had been developing a doctrine of the sultan's legitimacy in all religious matters; from that position he could recognize the legitimacy of non-Muslim rulers as long as they posed no threat to Islam. ${ }^{112}$ On both sides, of course, forces opposed to negotiating and pacting with the infidel applied whatever pressure they could; but it was not they who prevented any treaties from being signed prior to the eighteenth century.

In 1767 the sultan was able to accept the principles of reciprocity and lasting peace: "Peace shall be absolute at sea and on land, established with the most mutual and true amity between the two sovereigns and their respective vassals." The other articles, which dealt chiefly with navigation, commerce, and subjects' travels in the lands of the other party, were imprecise; to ratify the 1767 accord and solve problems that had developed over the years, the countries signed two new agreements in 1780 and 1785 and a new treaty in $1799 .{ }^{113}$ But the letter of the treaties was not always applied strictly, since Spain had to allow for customary law in North Africa, especially Morocco. The sultan, as not only a political but also a religious leader, had to provide for the welfare of his subjects. That meant, among other things, ensuring that a sufficient supply of food would be available at reasonable prices, so the sultan had to control prices for the common good, both when basic grains were abundant and when they were scarce. In the period $1777^{-1783}$ the sultan drew on the royal treasury to ease his subjects' difficulties - assisting those who lacked resources, exempting farmers from taxes, and offering loans on generous terms to merchants who could then buy wheat in Cádiz and Lisbon and resell it at normal prices. ${ }^{114}$

We believe that the Moroccan case was one of a "moral economy," though E.P. Thompson suggested modifications and nuances to that term. ${ }^{115}$ When wheat was scarce and large price increases were rumored, the sultan and the religious establishment would play the "paternalist" role, guaranteeing that

112 Windler, La diplomatie, 15; he relies on Dakhlia, Le divan des rois.

113 For all these agreements and others signed with Algiers, Tunis, Tripoli, and the Ottoman Empire see Cantillo, Tratados, convenios; quotation at 505 .

114 Abitbol, Histoire, 257.

115 Thompson, Customs in Common, especially the articles "The Moral Economy of the English Crowd in the Eighteenth Century," 185-258, and "The Moral Economy Reviewed," 259-351. 
the people could obtain the grain they needed. The population's only recourse was to defend their customary right to reasonable prices; that did not involve purely commercial considerations, and the market did not always have the last word. We know relatively little about the role played by the market, nor about the behavior of tribe members who were in imminent danger of famine. But it is important to note that the sultan himself was the chief commercial agent for exporting wheat, based on the stocks collected as taxes and stored in royal silos. ${ }^{116}$ On several occasions religious authorities denied Spanish merchants' demands for wheat or livestock, complaining that their export raised prices to the point where Moroccans could not afford them, and sometimes the sultan would prohibit their leaving the country. Even without a specific ban the people sometimes reacted with violence, blocking roads and impeding the arrival of grain at the ports. ${ }^{117}$

Ideology also entered into play. Spain refused to supply arms and military equipment to Morocco, but the ban was not always observed: many exceptions were made, especially for material needed to repair or arm Moroccan corsair ships. When the sultan had to defend a decision to export wheat even in a time of scarcity, he would argue to the religious establishment that the grain would be paid for with arms and munitions that could then be turned against the infidels. ${ }^{118} \mathrm{C}$. Windler has shown how in French-Tunisian relations the most important consideration in the end was that both parties could save face.

Another crucial element was the practice of gift exchange, which the Moroccan sultan employed to obtain his subjects' allegiance or submission. ${ }^{119}$ The gift - which might consist of a privilege or form of protection - created a debt of gratitude on the part of its receiver or client, who had to prove deserving of it. And although it was given freely, the client incurred an obligation to his patron and had to offer a counter-gift. While the interval in time between gift

116 For the wheat trade see Lourido Díaz, Marruecos y el mundo, 414-19.

117 Not coincidentally, prohibitions on exporting wheat were almost always issued in or after October, as happened in 1771 and 1772: Lourido Díaz, Marruecos y el mundo, 416. In 1784 the Spanish consul in Tangier warned the Secretariat of State that free exports of wheat from Casablanca might not continue much longer: "the people of this country are not very happy with this privilege, and some Moors have spoken to the Sovereign about the lack [of food] all along this coast from Tetouan to Salé, [saying] that it would be better to fill this urgent need with the wheat that leaves from Casablanca rather than to let the Christians take it": J.M. González Salmón to Count Floridablanca, 14 October 1784, AHN, Estado, leg. 4317 .

118 Lourido Díaz, Marruecos, 419-24.

119 For the role of the gift in Muslim societies in general and Morocco in particular see Saadani, Le don au Maghreb; Benabdelali, Le don et l'anti-économique; Bourquia, "Don et théatralité"; Maunier, Recherches sur les échanges rituels. 
and counter-gift could make them appear as disinterested and generous acts, they were in fact perceived as binding obligations. ${ }^{120}$

The sultan also used the gift in his relations with European countries, especially with their consuls based in Tangier. ${ }^{121}$ Here many misunderstandings arose, as the sultan's apparently disinterested generosity clashed with his European interlocutors' "economic" or accountancy-based rationality. Spanish consuls hewed to the treaties' stipulations about fees to be paid on various exported products, and their freedom to extract from Morocco, without hindrance, all the products they wanted. The sultan usually employed the gift exchange - which conditions the relationship between giver and receiver - to gain the Europeans' good will and force them to respond with counter-gifts.

A good example is the chain of gifts and counter-gifts between the sultan and the Spanish, as related by Spain's consul general in Tangier, Juan Manuel González Salmón. He wrote first about services performed by Spaniards and went on to explain the privileges granted by the sultan. It is a long account (though it concerns only the 1780s) but one worth quoting in full:

[Spain's] services and blandishments were compensated by the Sultan (aside from what he did for us during the war with the English, when he opened the port of Tangier to us and allowed our sentinels on his coast) with the three years of free trade that he gave the nation between $[17] 81$ and $[17] 83$ for exporting all kinds of fruits, sheep, and cattle from the ports of Larache, Tangier, and Tetouan free of duties. In those three years, what his customs-house lost just in the oxen and fowl exported to supply our army in Gibraltar and our blockade squadron amounted to many thousands of pesos. Beside the Canary Islanders that His Moroccan Majesty rescued from the savage Moors, his intercession in [17]83 saved the the wife and daughter of the governor of Mazalquivir as well as an officer of the Brabant Regiment and two soldiers. In [17] 85 he again allowed Spaniards to extract freely from those three ports all kinds of fowl, fresh and dried fruits, firewood, and charcoal; ships did not have to pay anchorage fees, from which he is estimated to have lost fifteen to twenty thousand duros a year. In addition, since the year [17] 88 we have enjoyed, in those three ports, a reduction in fees of two duros per head of cattle, ten

120 Mauss, The Gift; Windler, La diplomatie, 170.

121 I will not discuss here the exchanges of gifts between the sultan, princes, governors, and other Moroccan officials on the one hand and Spanish consuls, ambassadors, envoys, and merchants on the other, nor similar ones involving Spain and the Regencies of Algiers, Tunis, and Tripoli. 
reales de vellón per head of sheep, and five [reales] per fanega of dried peas compared to what other nations pay, plus an additional two per cent less for introducing European goods into every port in Morocco: because Spaniards and Moors, who are treated alike in this, pay ten and all the rest pay twelve. At the end of [17] 85 the port of Mogador began allowing Spaniards to load wheat, paying sixteen reales de vellón per fanega while all others were charged twenty-four; though the privilege was not enjoyed for long, several shipments were made to Cádiz. After that grace period, at my request, permission was given from the same port for the Canary Islands, though only one shipment of four thousand fanegas was made because wheat reached the islands from other sources and more from Morocco was not needed. Also in late $[17] 85$ that prince ceded exclusively to Spain the right to export grain from the ports of Rabat and Darbeyda [Casablanca] (paying a duty of sixteen reales per fanega). From the former they loaded about twenty thousand, but then the permission was revoked because of conflicts between its governor and customs officials; from the latter there has been continuous and abundant exportation both before and after the Spanish consulate was established there. Ships there are exempt from anchorage fees, and were they to be charged about a hundred duros, as they are in Mogador, this sum alone would amount to sixteen to eighteen thousand pesos - money that is saved and retained in the Kingdom. ${ }^{122}$

"Estos servicios y agasajos los ha recompensado aquel Soberano (prescindiendo de los que nos hizo en tiempo de la guerra con los Yngleses franqueándonos el Puerto de Tanger para el Apostadero, y costa para Vigias) con los tres años de franquicia desde 81 hasta 83 que concedió a la nación para extraer pr los Puertos de Larache, Tanger, y Tetuan, todo genero de frutos, ganado lanar, y Bacuno libre de derechos, que solo lo que perdió de recibir su Aduana en los Bueyes, y Aves que se sacaron para proveer el Exercito del Campo de Gibraltar y Esquadra del Bloqueo en dichos tres años importaron muchos miles de pesos: Ademas de los Españoles Canarios que S.M.M. a sacado de poder de los Moros Salvages, se rescataron de Argel por su intercesión el año de 83 la muger del Governador de Mazalquivir, su hija, un oficial del Reximiento de Bravante, y dos soldados. El año de 85 concedio también la gracia por los tres mencionados Puertos para que los españoles saquen libremente todo genero de Aves, frutas secas, y verdes, leña y carbón; y que las embarcaciones no paguen anclaje, que se regula pierde de recivir por esta franquicia anualmente de 15 a 20 mil duros: A esto se agrega que desde dicho año de 88 se goza en los mismos tres Puertos la rebaja de derechos de dos duros en cada caveza de ganado vacuno, 10 reales de vellón en la de lanar, 5 Ydem en cada fanega de legumbres con respecto a lo que pagan las demás Naciones, y un $2 \%$ menos que estas en la introducción de las mercancías de Europa pr todos los Puertos de Marruecos, porque los Españoles y los Moros, que en esto corren con igualdad, pagan un 10 y los demás 12. A últimos de 85 se concedio la gracia por el Puerto de Mogador para que los Españoles embarcasen trigo 
We must remember that all these privileges came from the sultan's initiative, as the Spanish consul acknowledged in writing of the monopoly on exporting wheat from Casablanca: "it is a proposal born of the sultan himself, who expresses his best wishes for putting it into practice."123 $\mathrm{He}$ went on to enumerate the Spanish Crown's counter-gifts to the sultan:

In [17]82 a gift was made to him that went to Tangier by order of Count O'Reilly, who was governor of Cádiz at the time, of no great import; a good felucca was built for him at about that time, and one of his frigates was repaired. In [17] 84 he was allowed a merchant ship for conveying gunpowder to Constantinople. In [17]85 Don Francisco Salinas y Moñino went to his court as Extraordinary Envoy and Minister Plenipotentiary to offer his compliments to His Majesty and take him a magnificent present from the King our master. In [17] 86 we repaired two of his frigates in Cádiz and one in Algeciras. In [17]87 in Cádiz, at the expense of the royal treasury, several doors and windows were made for him out of ebony with fine inlay. These are all the significant expenses of the Crown in the latest period of peace, together with the two warships that at His Majesty's request were sent to Constantinople and the Syrian coast; although there have been others, they were so small as to be not worth mentioning. ${ }^{124}$

pagando el derecho de 16 rs. vn. por cada fanega, y a los demás se les exigia 24 que aunque no se disfrutó por mucho tiempo se hicieron algunas expediciones para Cadiz: Por el mismo Puerto, después de concluida esta gracia se volvió a conceder a mi solicitud para las Yslas Canarias, que tampoco se hizo mas que una expedición de 4 mil fanegas por que acudió a dichas Yslas trigo de otros varios parages y no se necesitó llevar mas de Marruecos. Tambien a últimos de 85 cedió aquel Principe a la España exclusivamente los Puertos de Rebat y Darbeida para extraer granos (pagando el derecho de 16 rs de saca por fanega) Por el primero embarcaron como unas 20 mil y después se revocó el permiso por disensiones que tuvo entre aquel Governador y dependientes de Aduana, y en el segundo, antes de establecer la Casa Española que hay allí, y después, se ha hecho una extracccion seguida, y numerosa, donde también las embarcaciones estan libres de anclaje, y si les exigiera a razón de 100 duros, que cobran en Mogador, montaria solo este renglón la cantidad de 16 a 18 mil Pesos (que siempre es dinero que se ahorra y queda en el Reyno)"J.M. González Salmón to Count Floridablanca, Madrid, 9 October 1789, AHN, Estado, leg. 4321. Undoubtedly the most advantageous concession to Spain was the exclusive right to export wheat from Casablanca: Rodríguez Casado, La política marroquí, 354-59.

123 J.M. González Salmón to Count Floridablanca, 23 December 1785, AHN, Estado, leg. 4317.

124 "El año de 82 se le hizo un regalo que fue a Tanger por dirección del conde de O'Reilly a la sazon Governador de Cadiz, de corta consideración; se le construyó una buena Falua por aquel tiempo, y se le reparó una Fragata. El 84 se le facilitó una embarcación mercante para llevar polvora a Constantinopla. El 85 pasó a aquella Corte Dn. Francisco Salinas y Moñino con calidad de Embiado Extraordinario y Ministro Plenipotenciario para cumplimentar a S.M. y llevarle de parte del Rey Nro. Señor un magnifico regalo. El 86 se le 
While there is no mention here of a cash accounting, we can see the close relationship between the gift and the counter-gift.

Spain's secretaries of state, consuls, and other authorities involved in relations with Morocco realized the significance of the sultan's gifts and the need to respond to them with equivalent items or services. They satisfied these obligations in a variety of ways: repairing Moroccan ships in the yards at Cádiz and Cartagena, supplying vessels that conveyed the sultan's envoys to their destinations, making gifts of items that the sultan had ordered from Cádiz, and other similar gestures.

At first the Spaniards thought that the literal framework of the treaties had to be respected scrupulously by both parties; but by accepting the sultan's gifts to them - like the exclusive right to export wheat through Casablanca - they realized that matters were more complicated than that. They were also obliged to respect local customs in Morocco, and soon realized that the letter of the treaties could be obeyed only in part and so long as no serious political or economic problems arose between the parties. Consular representatives in Morocco thus embarked on a long, complex process of improvised adaptation to local laws and customs. They emerged from this experience in a fairly strong position - contrary to what has been believed, and even though scholarship has largely ignored them or considered their actions deficient. The issue needs further study and we shall not develop it further here, except for the aspect that interests us most: its repercussions on the activities of Moroccans in Spain. We shall also not concern ourselves with gift exchange, ${ }^{125}$ which soon became institutionalized but made a greater impact on Spanish policy toward Morocco than on Moroccan policy toward Spain.

What we do propose to analyze, especially in the next two chapters, is how Muslims who traveled to Spain for different reasons learned the rules of the game that operated on Spanish soil - rules that were defined in the language of treaties but were also tempered by local customs, although to a lesser degree than in Morocco. We shall pay special attention to the fact that Moroccan customs crossed the Strait of Gibraltar, even if only partially and occasionally. One reason this was possible was that Moroccans operated essentially

compusieron en Cadiz otras dos Fragatas, y una en Aljeciras. El 87 se le hicieron también en Cadiz a expensas de la Real Hacienda unas quantas Puertas y ventanas de Caoba con embutidos primorosos, que son todos los gastos de consideración que ha ocasionado a la Corona en esta ultima Paz, con los que hayan hecho los dos buques de guerra que a solicitud de S.M. fueron a Constantinopla y Costa de Syria, porque aunque ha habido algunos otros no merece la atención por su pequeñez": J.M. González Salmón to Count Floridablanca, Madrid, 9 October 1789, AHN, Estado, leg. 4321.

The general word for "gift" in Arabic is hiba, in Morocco hadiyya. 
with face-to-face, oral contacts; they had no consuls or commercial agents in Spanish ports. The literal language of the treaties placed their entire burden on Spanish consuls general in Tangier, who had to act in "the juridical spaces created through practice," that is, in the gaps between European law and Moroccan custom.

To this point it does not seem that Spanish-Moroccan bilateral relations (roughly similar to Spanish-Maghrebi ones in general) were very different from the ones that France and England maintained with North African countries always bearing in mind that Spain's power was weaker, and that it could not compete with those two nations on an equal footing or make similar demands on Morocco. For that very reason it had to lean more heavily on consensus, persuasion, and insistence on the common interests of the two countries.

Another issue is whether Spanish policy toward Muslim countries was either mistaken or inconsistent, and whether Spain's ambassadors and negotiatiors in charge of the treaties with Morocco, Algeria, Tunis, Tripoli, and the Ottoman Empire were well chosen. Some were unquestionably better than others, but in the end peaceful relations proved lasting. There were few important conflicts with those countries: only with Morocco (wars in 1774-1775 and 1791-1792, the African War in 1859-1860) and Algeria (in the 1820s and 183os over unpaid debts). There were far fewer clashes with Tunis and none at all with Tripoli and the Ottoman Empire.

Spain's climate of good relations with Morocco contrasted with the pressure exerted there by English and French agents and diplomats. The Moroccan sultan ignored English pledges to help him conquer Ceuta and other Spanish presidios, and even gave the Spanish navy a foothold in Tangier while it was blockading Gibraltar. Morocco took Spain's side against France, especially after the outbreak of the French Revolution, when Spain played to the utmost the card of a common struggle against the French, those enemies of religion. ${ }^{26}$ When Napoleon's troops invaded the Iberian Peninsula, the sultan again turned a deaf ear to French promises of aid in conquering Spain's North African presidios. Morocco hastened to facilitate the treaties that Spain signed with Algiers and Tunis, and Algiers performed the same service for the Spanish monarchy and Tunis; Tripoli mediated between Spain and Algiers. Spain served as intermediary between Morocco and Malta, Naples, and the Two Sicilies. These

126 Abitbol, Histoire, 276-78; Arribas Palau, "Marruecos de la muerte de Mawlay al-Yazid" and "La ayuda prestada a España." 
examples should be sufficient proof that Spain did not deal with North Africa in the spirit of crusade or jihad, as has often been alleged. Those Muslim countries would gain by bringing more countries into the play of friendly rivals, rather than by abandoning the field to England and France; this posture served to mitigate their hegemony somewhat.

It is true that we must pay attention to whether articles of the treaties of peace and commerce were obeyed or not; to the degree of reciprocity in exchanges of gifts and counter-gifts, and their timeliness; and to the degree of respect shown for the other party's local customs. In Chapters 6 and 7 we will see that some unfortunate incidents were provoked by Moroccan envoys, emissaries, and ship captains. While we will not consider conflicts between Spaniards and Moroccans in the Sharifian Empire, we can mention here that they were significantly reduced - a conclusion contrary to that of many historians, at least before the present time.

Nevertheless, the almost century-long period of peaceful Hispano-Moroccan relations from 1767 to 1859 deteriorated as the nineteenth century advanced. Both countries suffered economic, social, and political reverses at that time, and the decay of their mutual relations contributed to sinking the two countries even further in decadence and weakness. Spain joined the European colonizing nations - though through a back door - and Morocco the ranks of the colonized, while the rest of the North African regencies suffered a similar fate. 